\title{
Nutrient content and accumulation in sugarcane under mineral fertilization and high doses of vinasse
}

\section{Teor e acúmulo de nutrientes em cana-de-açúcar sob adubação mineral e doses elevadas de vinhaça}

\author{
Monalisa Soares Costa ${ }^{1 *} ;$ Mário Monteiro Rolim²; Gerônimo Ferreira da Silva²; \\ Djalma Euzébio Simões Neto ${ }^{3}$; Elvira Maria Regis Pedrosa ${ }^{2}$
}

\section{Highlights}

Effect of vinasse doses up to $1200 \mathrm{~m}^{3} \mathrm{ha}^{-1}$ on nutrient absorption by sugarcane. Interaction between nutrients at high doses of vinasse in the nutrition of sugarcane. Tolerance of sugarcane to vinasse.

Nutritional supply of sugarcane with application of vinasse.

\begin{abstract}
Vinasse, a waste from ethanol production, has been widely used as a means of fertigation in sugarcane. However, high dose limits application at and its effects on nutrient absorption and accumulation by the crop are not known. The aim of this study was to evaluate and compare, during the initial development of sugarcane, the effect of mineral fertilization and high doses of vinasse on the macronutrient and sodium contents of the top visible dewlap (TVD) leaf and their respective accumulations in the aerial part of the crop. The experiment was carried out in 100- $\mathrm{dm}^{3}$ pots filled with Argisol. The treatments consisted of five doses of vinasse $(0,150$, 300,600 and $1200 \mathrm{~m}^{3} \mathrm{ha}^{-1}$ ) and an additional treatment with no vinasse and mineral fertilizer (500 kg ha-1 of the NPK 14-24-18 formulation). The levels of nitrogen, phosphorus, potassium, calcium, magnesium and sodium were evaluated in the TVD leaf at 120 days after planting and their accumulation in the aerial part of the plant at 210 days. Data were subjected to analysis of variance and compared using regression analysis and orthogonal contrasts. The vinasse doses applied did not adequately nourish the crop in macronutrients. Mineral fertilization provided higher $\mathrm{N}$ and $\mathrm{P}$ levels. The highest doses of vinasse provided higher levels of $\mathrm{K}$, $\mathrm{Ca}$ and $\mathrm{Mg}$ and larger accumulations of $\mathrm{N}, \mathrm{P}, \mathrm{K}$ and $\mathrm{Na}$, but were detrimental to the accumulation of $\mathrm{Ca}$. The descending order of accumulation of macronutrients and sodium with mineral fertilization was $\mathrm{P}>\mathrm{Ca}>\mathrm{N}>\mathrm{K}>$ $\mathrm{Mg}>\mathrm{Na}$. For the application of vinasse, the descending order was $\mathrm{K}>\mathrm{P}>\mathrm{Ca}>\mathrm{N}>\mathrm{Na}>\mathrm{Mg}$. In the absence of mineral fertilization and vinasse, the descending order was $\mathrm{P}>\mathrm{Ca}>\mathrm{K}>\mathrm{N}>\mathrm{Mg}>\mathrm{Na}$.
\end{abstract}

Key words: Saccharum officinarum. Mineral nutrition. Residue use.

$1 \mathrm{PhD}$ in Agricultural Engineering, Rural Federal University of Pernambuco, UFRPE, Recife, PE, Brazil. E-mail: monalisa_ sc@hotmail.com

2 Profs. PhD, Agricultural Engineering Department, UFRPE, Recife, PE, Brazil. E-mail: mariorolim10@uol.com.br; geronimo. silva@ufrpe.br; elvira.pedrosa@ufrpe.br

3 PhD, Coordinator of the Carpina Sugarcane Experimental Station, UFRPE, Carpina, PE, Brazil. E-mail: djalmasneto@ hotmail.com

* Author for correspondence

Received: June 16, 2020 - Approved: Aug, 24, 2020 


\section{Resumo}

A vinhaça, resíduo da produção do etanol, vem sendo amplamente utilizada como meio de fertirrigação da cana-de-açúcar, entretanto, não se conhece os limites da aplicação em altas doses e seus efeitos na absorção e acúmulo de nutrientes pela cultura. Objetivou-se avaliar e comparar, durante o desenvolvimento inicial da cana-de-açúcar, o efeito da adubação mineral e doses elevadas de vinhaça sobre o teor de macronutrientes e de sódio na folha diagnóstico e seus respectivos acúmulos na parte aérea da cultura. O experimento foi conduzido em vasos de $100 \mathrm{dm}^{3}$ preenchidos com um Argissolo. Os tratamentos consistiram de cinco doses de vinhaça $\left(0,150,300,600\right.$ e $\left.1200 \mathrm{~m}^{3} \mathrm{ha}^{-1}\right)$ e um tratamento adicional com ausência de vinhaça e adubação mineral (500 kg ha-1 da formulação NPK 14-24-18). Os teores de nitrogênio, fósforo, potássio, cálcio, magnésio e sódio foram avaliados na folha diagnóstico aos 120 dias após o plantio e seus acúmulos na parte aérea da planta aos 210 dias. Os dados foram submetidos à análise de variância e comparados mediante análise de regressão e contrastes ortogonais. As doses de vinhaça aplicadas não nutriram adequadamente a cultura em macronutrientes. A adubação mineral propiciou a obtenção de maiores teores de $\mathrm{N}$ e P. As doses mais elevadas de vinhaça proporcionaram maiores teores de $\mathrm{K}$, Ca e Mg e, maiores acúmulos de $\mathrm{N}, \mathrm{P}, \mathrm{K}$ e Na, porém, desfavoreceram o acúmulo de $\mathrm{Ca}$. A ordem decrescente de acúmulo dos macronutrientes e do sódio com a adubação mineral foi: $\mathrm{P}>\mathrm{Ca}>\mathrm{N}>\mathrm{K}>\mathrm{Mg}>\mathrm{Na}$. Para a aplicação de vinhaça a ordem decrescente foi: $\mathrm{K}>\mathrm{P}>\mathrm{Ca}>\mathrm{N}>\mathrm{Na}>\mathrm{Mg}$. Já para as ausências de adubação mineral e de vinhaça a ordem decrescente foi: $\mathrm{P}>\mathrm{Ca}>\mathrm{K}>\mathrm{N}>\mathrm{Mg}>\mathrm{Na}$.

Palavras-chave: Saccharum officinarum. Nutrição mineral. Aproveitamento de resíduo.

\section{Introduction}

Sugarcane is an important crop for the economy and development of Brazil, as, among other factors, it is a raw material for the processing of ethanol, a biofuel that has been widely used in the country and worldwide. However, the ethanol industry generates vinasse, a waste made up of about $93 \%$ water and $7 \%$ total solids. The solid fraction is known to consist of $75 \%$ organic matter and $25 \%$ minerals, among which $\mathrm{K}$ predominates (Pazuch et al., 2017).

Vinasse is commonly used as a means of meeting part of the nutritional requirement of sugarcane. Conversely, the compound has an acid $\mathrm{pH}$, high electrical conductivity (Christofoletti, Escher, Correia, Marinho, \& Fontanetti, 2013) and disproportional distribution of mineral nutrients in relation to the nutritional need of sugarcane, directly affecting the ability of the plant to properly nourish. Thus, situations of deficiency or toxicity by a certain element may ensue due to nutrient imbalance.

Inadequate management of the amount of vinasse applied causes unfavorable chemical changes in the soil and compromises the development of sugarcane due to the high concentrations of $\mathrm{K}, \mathrm{Ca}$ and $\mathrm{Na}$ present in the compound (Christofoletti et al., 2013; Ortegón, Arboleda, Candela, Tamoh, \& Valdes-Abellan, 2016; Garcia, Souza, Souza, Christofoletti, \& Fontanetti, 2017). This nutritional imbalance causes saturation of the soil with these nutrients and, consequently, antagonistic relationships, especially those of $\mathrm{K}$ with $\mathrm{Ca}$ and $\mathrm{Na}$ (Aquino, Medina, Brito, \& Fonseca, 2015; Rhodes, Miles, \& Hughes, 2018), ultimately compromising the nutritional balance of the crop. 
According to E. C. A. Oliveira et al. (2010), sugarcane demands K predominantly over $\mathrm{Ca}, \mathrm{N}, \mathrm{Mg}$ and $\mathrm{P}$. In this respect, a recommended fertilization strategy for the crop with vinasse doses of up to $300 \mathrm{~m}^{3} \mathrm{ha}^{-1}$ can meet its nutritional requirements (especially of potassium), promote stalk production and reduce the amount of mineral fertilizer to be applied (Barbosa, Arruda, Pires, Silva, \& Sakai, 2012). Nonetheless, no consolidated information exists in the literature regarding the application of vinasse doses higher than 300 $\mathrm{m}^{3}$ ha $^{-1}$ on nutrient absorption by sugarcane. Moreover, studies comparing the application of mineral fertilizer versus vinasse doses - high doses, mainly - on the nutritional behavior of the crop are still incipient.

Therefore, research investigating the management of the vinasse application to the soil for the mineral nutrition in sugarcane is warranted. Likewise, studies comparing mineral fertilization with use of vinasse for fertilizing the crop are of great relevance, as they can provide important information regarding the possibility of using vinasse in the partial or total replacement of mineral fertilization.

Among the methods used to evaluate and compare the effects of application of mineral fertilizer and vinasse doses on the initial development of sugarcane is the nutritional status of the crop, which is determined evaluating the top visible dewlap (TVD) leaf and the amount of nutrients accumulated in the aerial part of the plant. According to Grangeiro et al. (2011), these data are essential, as they can allow for increased efficiency of fertilization programs and the adequate supply of nutrients in a readily assimilable form. In this way, the crop can achieve the maximum productive capacity, especially when this is associated with nutritional analysis of the plants in a given moment of their cycle.

This study proposes to examine and compare the effect of mineral fertilization and high doses of vinasse on the macronutrient and sodium contents of the TVD leaf and their respective accumulations in the aerial part of the crop during sugarcane initial development.

\section{Materials and Methods}

The experiment was carried out in pots with volume capacity of $100 \mathrm{dm}^{3}$, in a protected environment located at $8^{\circ} 01^{\prime} 05^{\prime \prime}$ $\mathrm{S}$ and $34^{\circ} 56^{\prime} 48^{\prime \prime} \mathrm{W}$, at altitude of $6.49 \mathrm{~m}$. The soil used for filling the pots was an abrupt Dystrophic-Cohesive Yellow Argisol with a sandy loam texture, collected at 7०51'13" S and $35^{\circ} 14^{\prime} 10^{\prime \prime} \mathrm{W}$, in the municipality of Carpina, PE, Brazil, in a region of coastal plateau soils. Chemical characterization of the soil followed before the implementation of the experiment is described in Table 1. Vinasse was collected in the rural area of Lagoa de Itaenga, in the "Mata Norte" region of the state of Pernambuco, Brazil, in the pipeline from the distillery to the distribution pond. The vinasse chemical characterization, performed immediately after collection, is shown in Table 2. 
Table 1

Chemical attributes of the Argisol before application of vinasse

\begin{tabular}{|c|c|c|c|c|c|}
\hline Parameter & Unit & $\begin{array}{l}\text { Result } \\
0-20 \mathrm{~cm}\end{array}$ & Classification* & $\begin{array}{c}\text { Result } \\
20-40 \mathrm{~cm}\end{array}$ & Classification* \\
\hline $\mathrm{pH}$ & & 5.80 & Good & 5.60 & Good \\
\hline Phosphorus & $\mathrm{mg} \mathrm{dm}^{-3}$ & 8.00 & Very low & 5.00 & Very low \\
\hline Potassium & cmolc dm ${ }^{-3}$ & 0.09 & Low & 0.06 & Low \\
\hline Calcium & cmolc dm ${ }^{-3}$ & 1.75 & Medium & 1.25 & Medium \\
\hline Magnesium & cmolc dm ${ }^{-3}$ & 0.75 & Medium & 0.75 & Medium \\
\hline Sodium & cmolc dm ${ }^{-3}$ & 0.08 & Medium & 0.07 & Medium \\
\hline CEC & cmolc dm ${ }^{-3}$ & 5.80 & Medium & 5.60 & Medium \\
\hline Effective CEC & cmolc dm -3 $^{3}$ & 2.75 & Medium & 2.25 & Medium \\
\hline Potential acidity & cmolc dm ${ }^{-3}$ & 3.13 & Medium & 3.46 & Medium \\
\hline SB & cmolc dm ${ }^{-3}$ & 2.70 & Medium & 2.10 & Medium \\
\hline Base saturation & $\%$ & 46.00 & Medium & 38.00 & Medium \\
\hline Organic matter & $\%$ & 2.45 & Medium & 2.05 & Medium \\
\hline ESP & $\%$ & 1.37 & Non-sodic & 1.25 & Non-sodic \\
\hline Sand & $\%$ & 75.50 & & 73.85 & \\
\hline Silt & $\%$ & 19.80 & Sandy-loam & 21.84 & Sandy-loam \\
\hline Clay & $\%$ & 4.70 & & 4.31 & \\
\hline
\end{tabular}

${ }^{*}$ Classification based on Ribeiro, Guimarães and Alvarez (1999); $\mathrm{pH}$ in water (1:2.5); Phosphorus extracted by Mehlich-1 (double acid extractor: $\mathrm{H} 2 \mathrm{SO} 40.0125 \mathrm{~mol} \mathrm{~L}^{-1}+\mathrm{HCl} 0.05 \mathrm{~mol} \mathrm{~L}^{-1}$ ); Potassium and sodium extracted with $\mathrm{HCl} 0.05 \mathrm{~mol} \mathrm{~L}^{-1}$; Calcium and magnesium extracted with $\mathrm{KCl} 1 \mathrm{~mol} \mathrm{~L}^{-1}$; Potential acidity $(\mathrm{H}+\mathrm{Al})$ extracted with $0.5 \mathrm{M}$ calcium acetate and pH 7.0; $\mathrm{CEC}$ = cation-exchange capacity; $\mathrm{SB}$ = sum of exchangeable bases; $\mathrm{ESP}$ = exchangeable sodium percentage.

To fill each pot, a layer of gravel \#0 was added to the bottom and geotextile fabric was laid on top of it. Each pot was filled with $77 \mathrm{dm}^{3}$ of soil in a $55-\mathrm{cm}$ deep layer arranged so that the lower half of the pot contained the portion collected at the depth of $20-40 \mathrm{~cm}$ and the upper half contained the soil collected at the depth $0-20 \mathrm{~cm}$, with a porosity of $46.15 \%$, aiming to maintain an apparent density close to $1.4 \mathrm{~g} \mathrm{~cm}^{-3}$. 


\section{Table 2}

Chemical attributes of the Argisol before application of vinasse

\begin{tabular}{lcc} 
Parameter & Supply water & Vinasse \\
\hline $\mathrm{pH}$ & 6.3 & 4.2 \\
Electrical conductivity $\left(\mathrm{dS} \mathrm{m}^{-1}\right)$ & 0.128 & 15.06 \\
Calcium $\left(\mathrm{mg} \mathrm{L}^{-1}\right)$ & 0.9 & 888.3 \\
Magnesium $\left(\mathrm{mg} \mathrm{L}^{-1}\right)$ & 0.6 & 395.3 \\
\hline Sodium $\left(\mathrm{mg} \mathrm{L}^{-1}\right)$ & 5.1 & 729.1 \\
\hline Potassium $\left(\mathrm{mg} \mathrm{L}^{-1}\right)$ & 2.5 & 1053 \\
Total nitrogen $\left(\mathrm{mg} \mathrm{L}^{-1}\right)$ & - & 51.8 \\
\hline Total phosphate $\left(\mathrm{mg} \mathrm{L}^{-1}\right)$ & - & 6.78 \\
\hline Carbon $\left(\mathrm{mg} \mathrm{L}^{-1}\right)$ & - & $1,032.5$ \\
\hline Total solids $\left(\mathrm{mg} \mathrm{L}^{-1}\right)$ & - & 22,368 \\
Biochemical oxygen demand $\left(\mathrm{BOD}_{5.20}\right)\left(\mathrm{mg} \mathrm{L}^{-1}\right)$ & - & 12,300 \\
Chemical oxygen demand $\left(\mathrm{mg} \mathrm{L}^{-1}\right)$ & - & 27,250
\end{tabular}

The experiment was laid out in a completely randomized design with six treatments and six replicates. The treatments were represented by five vinasse doses, namely, 0 (D0), 150 (D150), 300 (D300), 600 (D600) and 1200 (D1200) $\mathrm{m}^{3} \mathrm{ha}^{-1}$, and an additional treatment corresponding to mineral fertilization (MF). These doses were chosen based on the dose of $300 \mathrm{~m}^{3} \mathrm{ha}^{-1}$, which is recommended as the adequate dose for the potassium requirement of a sugarcane cycle.

The amounts of macronutrients and sodium present in each vinasse dose were estimated for the equivalent in $\mathrm{kg} \mathrm{ha}^{-1}$ and are described in Table 3. Vinasse was applied manually, with the quantities being calculated in proportion to the surface area of the pots, at 20 days before sugarcane was planted.

Table 3

Amounts of nitrogen $(\mathrm{N})$, phosphorus $\left(\mathrm{P}_{2} \mathrm{O}_{5}\right)$, potassium $\left(\mathrm{K}_{2} \mathrm{O}\right)$, calcium $(\mathrm{Ca})$, magnesium $(\mathrm{Mg})$ and sodium (Na) determined for each of the vinasse doses applied

\begin{tabular}{|c|c|c|c|c|c|c|}
\hline Dose & $\mathrm{N}$ & $\mathrm{P}_{2} \mathrm{O}_{5}$ & $\mathrm{~K}_{2} \mathrm{O}$ & $\mathrm{Ca}$ & $\mathrm{Mg}$ & $\mathrm{Na}$ \\
\hline$m^{3} h a^{-1}$ & ---------- & ------ & - kc & ----------- & ---------- & ------------- \\
\hline 150 & 7.77 & 1.01 & 189.00 & 133.24 & 59.29 & 109.36 \\
\hline 300 & 15.54 & 2.03 & 378.00 & 266.49 & 118.59 & 218.73 \\
\hline 600 & 31.08 & 4.07 & 756.00 & 532.98 & 237.18 & 437.46 \\
\hline 1200 & 62.16 & 8.14 & 1512.00 & 1065.96 & 474.36 & 874.92 \\
\hline
\end{tabular}


Mineral fertilization consisted of a 1424-18 NPK dose corresponding to $500 \mathrm{~kg}$ ha $^{-1}$ considering the upper area of the pot for proportional dosing. Ammonium sulfate was used as the $\mathrm{N}$ source; single superphosphate as the $\mathrm{P}_{2} \mathrm{O}_{5}$ source; and potassium chloride as the $\mathrm{K}_{2} \mathrm{O}$ source. These were applied based on soil analysis carried out before the start of the experiment and on the fertilization recommendation for the state of Pernambuco by Cavalcanti et al. (2008). All mineral fertilization was applied before the planting of sugarcane, with no need for fertilization after the beginning of the crop cycle.

The sugarcane cultivar evaluated was RB867515, with four billets planted in each pot, each containing one bud. After germination, thinning was performed to leave only three billets. The crop was irrigated manually and in an equal amount for all plots, following a 2-day irrigation shift, according to the need of the crop, and maintaining soil moisture at field capacity. Throughout the experimental period ( 210 days), about $160 \mathrm{dm}^{3}$ of water were applied to each pot, that is, $851 \mathrm{~mm}$.

The levels of $\mathrm{N}, \mathrm{P}, \mathrm{K}, \mathrm{Ca}, \mathrm{Mg}$ and $\mathrm{Na}$ were analyzed on the top visible dewlap (TVD) leaf $(+1)$ at 120 days after planting. The +1 leaf was considered to be the first leaf with a visible ligule. In removing this leaf for analysis, the extremities were discarded and only the middle third part was sent for laboratory analysis. The central nerve was also discarded (Martinez, Carvalho, \& Souza, 1999). At 210 days, macronutrient ( $N, P, K, C a$ and $\mathrm{Mg}$ ) and $\mathrm{Na}$ accumulation in the aerial part of the plant (stem, tip and leaves) was quantified. Accumulation was determined by multiplying each of the levels of nutrients found by the amount of dry biomass accumulated in the respective aerial part of the plants.
To determine both the content (120 days) and accumulation (210 days) of macronutrients and $\mathrm{Na}$ by the crop, all the plant material was taken to the laboratory and washed with deionized water. Subsequently, the material was packed in paper bags duly identified with the respective treatments and dried in a forced-air oven $\left(65^{\circ} \mathrm{C}\right)$ until a constant dry biomass was achieved. Next, the dry material was processed in a Wiley mill with a 2-mm sieve and placed in closed containers for later quantification of macronutrients and $\mathrm{Na}$.

Macronutrients ( $\mathrm{P}, \mathrm{K}, \mathrm{Ca}$ and $\mathrm{Mg}$ ) and $\mathrm{Na}$ were extracted from plant tissue in a closed system using a microwave oven as a source of heat and concentrated nitric acid $\left(\mathrm{HNO}_{3}\right)$ to digest the dry matter. For $\mathrm{N}$, sulfuric digestion was performed in a digester block according to the methodology proposed by F. C. Silva (2009). Total N was quantifiedby the Kjeldahl steam distillation method; $\mathrm{K}$ and $\mathrm{Na}$ by flame photometry; $\mathrm{P}$ by the colorimetric molybdovanadate method; and $\mathrm{Ca}$ and $\mathrm{Mg}$ were determined by atomic absorption spectrophotometry.

The obtained data were subjected to analysis of variance by the $F$ test. When significant effects were detected, regression analysis (vinasse doses) was performed at $5 \%$ probability. An analysis was also carried out using orthogonal contrasts to compare mineral fertilization versus vinasse doses (MF $\times$ vinasse (D150 to D1200)); mineral fertilization versus non-application of vinasse (MF $\times$ D0); mineral fertilization versus vinasse dose of 300 $\mathrm{m}^{3} \mathrm{ha}^{-1}$ (MF $\left.\times \mathrm{D} 300\right)$; mineral fertilization versus vinasse dose of $1200 \mathrm{~m}^{3} \mathrm{ha}^{-1}$ (MF $\times$ D1200); and non-application of vinasse versus all vinasse doses (D0 $\times$ vinasse (D150 to D1200)). 


\section{Results and Discussion}

\section{Nutritional status}

The levels of the macronutrients evaluated in the TVD (+1) leaf were significantly influenced by the treatments. However, the same was not true for $\mathrm{Na}$ (Table 4). Of the evaluated contrasts (Table 5), for $\mathrm{N}$, a difference was only detected for MF versus the vinasse dose corresponding to $300 \mathrm{~m}^{3} \mathrm{ha}^{-1}$ (D300), with average leaf $\mathrm{N}$ contents of $15.9 \mathrm{~g} \mathrm{~kg}^{-1}$ obtained with the application of MF and $11.8 \mathrm{~g} \mathrm{~kg}^{-1}$ with the application of D300 (Table 4).

At 120 days after planting, the vinasse doses applied were not sufficient to provide an $\mathrm{N}$ content considered appropriate in the TVD leaf (Figure 1a). The highest vinasse dose applied (1200 $\left.\mathrm{m}^{3} \mathrm{ha}^{-1}\right)$ provided a leaf $\mathrm{N}$ content of $12.9 \mathrm{~g} \mathrm{~kg}^{-1}$, nearing the lower limit considered adequate for the crop (12 to $25 \mathrm{~g}$ $\mathrm{kg}^{-1}$ ) by F. C. Silva (2009).

\section{Table 4}

Effect of mineral fertilizer (MF) and vinasse doses (D0 to D1200) on the levels of nitrogen (N), phosphorus $(\mathrm{P})$, potassium $(\mathrm{K})$, calcium $(\mathrm{Ca})$, magnesium $(\mathrm{Mg})$ and sodium $(\mathrm{Na})$ in the top visible dewlap leaf 120 days after planting

\begin{tabular}{|c|c|c|c|c|c|c|c|c|c|}
\hline \multirow{2}{*}{$\begin{array}{c}\text { Nutrient } \\
\left(\mathrm{g} \mathrm{kg}^{-1}\right)\end{array}$} & \multicolumn{8}{|c|}{ Treatment } & \multirow{2}{*}{$\begin{array}{c}\text { Reference } \\
\text { values }^{3}\end{array}$} \\
\hline & MF & DO & D150 & D300 & D600 & D1200 & $F$ & P-value ${ }^{1}$ & \\
\hline $\mathrm{N}$ & $15.90 \pm 1.14^{2}$ & $14.88 \pm 1.14$ & $10.64 \pm 0.81$ & $11.84 \pm 0.81$ & $12.45 \pm 0.81$ & $12.75 \pm 0.81$ & 3.83 & 0.0108 & $18-25$ \\
\hline $\mathrm{P}$ & $1.47 \pm 0.09$ & $1.36 \pm 0.09$ & $1.28 \pm 0.07$ & $0.96 \pm 0.07$ & $1.05 \pm 0.07$ & $1.08 \pm 0.07$ & 6.20 & 0.0008 & $1.5-3.0$ \\
\hline $\mathrm{K}$ & $12.85 \pm 1.15$ & $12.25 \pm 1.15$ & $12.60 \pm 0.81$ & $14.09 \pm 0.81$ & $14.74 \pm 0.81$ & $18.15 \pm 0.81$ & 8.57 & $<0.0001$ & $10-16$ \\
\hline $\mathrm{Ca}$ & $0.84 \pm 0.21$ & $1.26 \pm 0.21$ & $1.06 \pm 0.15$ & $0.59 \pm 0.15$ & $1.35 \pm 0.25$ & $2.00 \pm 0.15$ & 10.00 & $<0.0001$ & $2.0-8.0$ \\
\hline $\mathrm{Mg}$ & $0.73 \pm 0.05$ & $0.84 \pm 0.05$ & $0.75 \pm 0.03$ & $0.65 \pm 0.05$ & $0.86 \pm 0.05$ & $1.0 \pm 0.05$ & 11.78 & $<0.0001$ & $1.0-3.0$ \\
\hline $\mathrm{Na}$ & $1.70 \pm 0.42$ & $1.67 \pm 0.42$ & $2.63 \pm 0.30$ & $1.75 \pm 0.30$ & $1.53 \pm 0.30$ & $1.52 \pm 0.30$ & 1.94 & 12.47 & - \\
\hline
\end{tabular}

${ }^{1}$ Significant results at $5 \%$ (p-value $\left.<0.05\right)$. ${ }^{2}$ Mean \pm standard error. F: F value calculated from analysis of variance. ${ }^{3} \mathrm{Values}$ considered adequate in the top visible dewlap leaf, in $\mathrm{g} \mathrm{kg}^{-1}$, according to F. C. Silva (2009).

\section{Table 5}

Orthogonal contrasts comparing the effect of mineral fertilizer (MF) and vinasse doses (D0 to D1200) on the levels of nitrogen $(\mathrm{N})$, phosphorus $(\mathrm{P})$, potassium $(\mathrm{K})$, calcium $(\mathrm{Ca})$ and magnesium $(\mathrm{Mg})$ in the top visible dewlap leaf of the sugarcane crop

\begin{tabular}{|c|c|c|c|c|c|}
\hline \multirow{2}{*}{ Contrast } & \multicolumn{5}{|c|}{ F-value } \\
\hline & $\mathrm{N}$ & $\mathrm{P}$ & K & $\mathrm{Ca}$ & $\mathrm{Mg}$ \\
\hline MF $\times$ Vinasse (D150 to D1200) & $3.11^{\mathrm{NS}}$ & $9.00^{*}$ & $3.15^{\mathrm{NS}}$ & $3.44^{\mathrm{NS}}$ & $3.27^{\mathrm{NS}}$ \\
\hline $\mathrm{MF} \times \mathrm{D} 0$ & $2.30^{\mathrm{NS}}$ & $11.42^{*}$ & $48.91^{*}$ & $6.29 *$ & $6.76^{*}$ \\
\hline MF $\times$ D300 & $4.70^{*}$ & $18.85^{*}$ & $4.72^{*}$ & $8.68^{*}$ & $10.17^{*}$ \\
\hline MF $\times$ D1200 & $0.40^{N S}$ & $0.60^{N S}$ & $0.37^{\mathrm{NS}}$ & $3.03^{N S}$ & $2.63^{N S}$ \\
\hline D0 $\times$ Vinasse (D150 to D1200) & $0.00^{\mathrm{NS}}$ & $1.27^{\mathrm{NS}}$ & $67.52^{*}$ & $39.08^{*}$ & $40.08^{*}$ \\
\hline
\end{tabular}

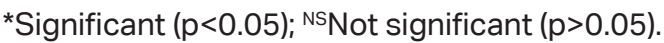


Given the insignificance of the contrast between MF and D1200 and the proximity of results of the $\mathrm{N}$ levels in the leaf obtained with the application of the doses of D600 (12.8g $\mathrm{kg}^{-1}$ ) and D1200 (12.9 $\mathrm{g} \mathrm{kg}^{-1}$ ) (Figure 1a), it can be inferred that the dose of $600 \mathrm{~m}^{3} \mathrm{ha}^{-1}$ complemented with mineral fertilizer can be used as a strategy for producers who have this waste available on their farms, which will bring economic and environmental benefits.

The inadequate supply of $\mathrm{N}$ for sugarcane, demonstrated by $\mathrm{N}$ levels in TVD leaf lower than the adequate for the crop, could be an after reflect of the low concentration of $\mathrm{N}$ provided by the vinasse. According to Meyer (2013), along with $\mathrm{K}, \mathrm{N}$ is the nutrient most absorbed by sugarcane. Moreover, $\mathrm{N}$ is responsible for $40 \%$ of the plant dry biomass by in the initial growth phase (Franco et al., 2011).
Another factor that may have contributed to the $\mathrm{N}$ levels being below the ideal in the leaf was the low concentration of $P$ in vinasse, which leads to a low concentration of the element in the soil and, consequently, inadequate supply of $\mathrm{P}$ to the plants (Figure 1b). The $P$ concentration found in vinasse was lower than that of $N$, and because $P$ and $\mathrm{N}$ act synergistically (Malavolta, 2006), a higher concentration of $P$ in vinasse and, consequently, in the soil, possibly contributed to a better use of the available $\mathrm{N}$ in vinasse and a higher $\mathrm{N}$ content in the TVD leaf of the crop. The test of contrasts performed for the $P$ content in the TVD leaf (Table 5 ) revealed significant differences for the contrasts of MF $\times$ vinasse doses (D150 to D1200), MF $\times$ D0 and MF $\times$ D300. 
(a)

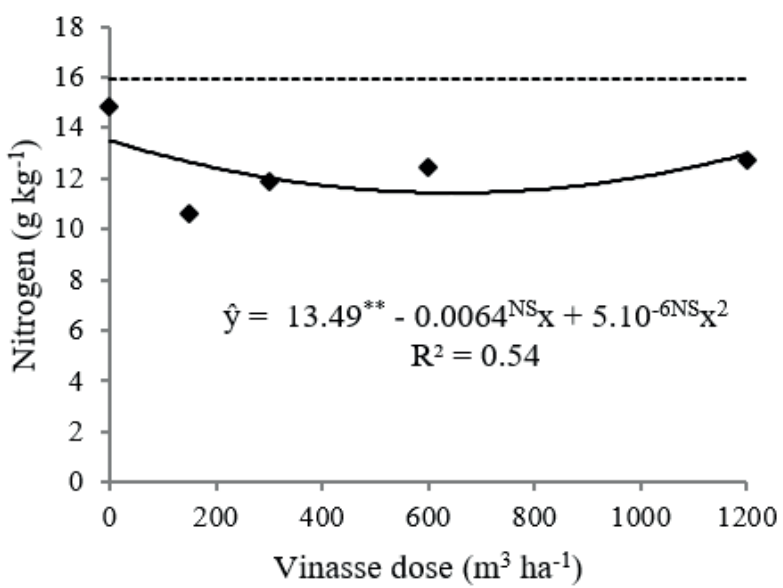

(c)

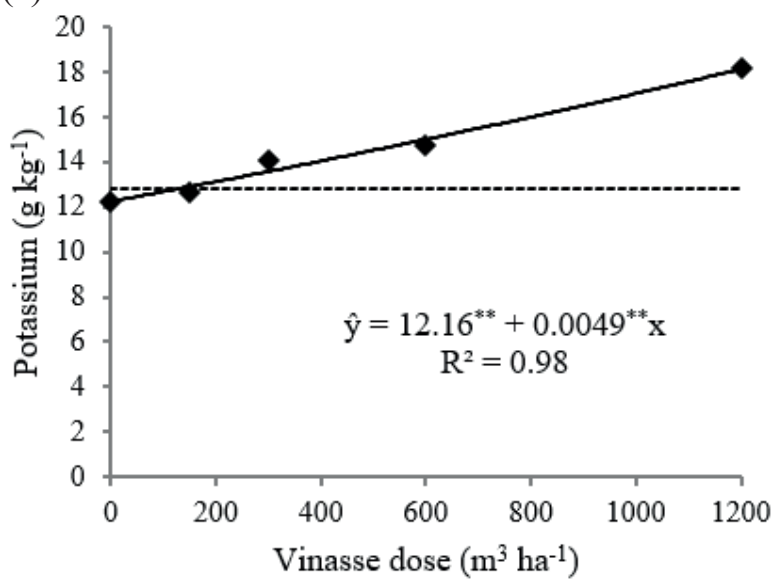

(e)

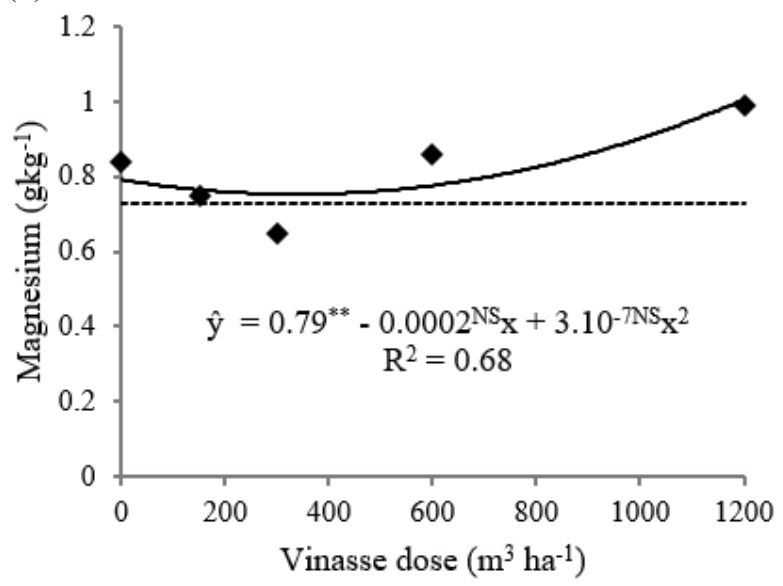

(b)

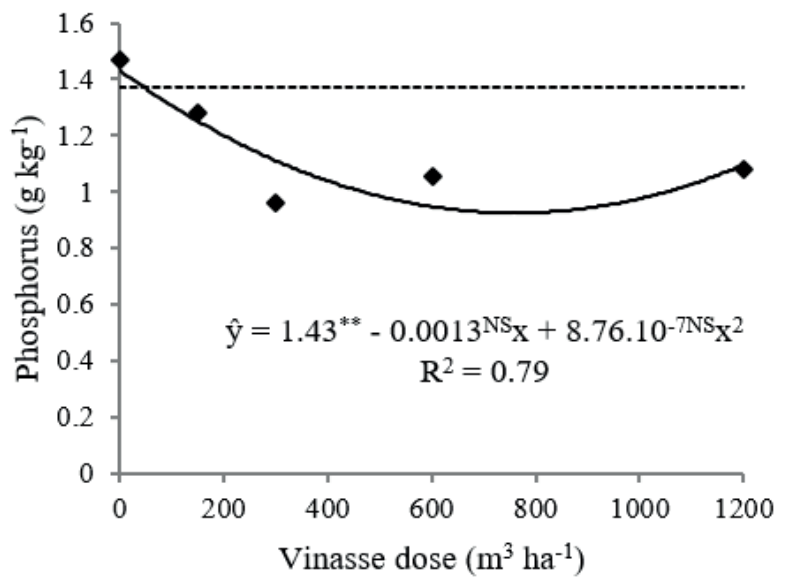

(d)

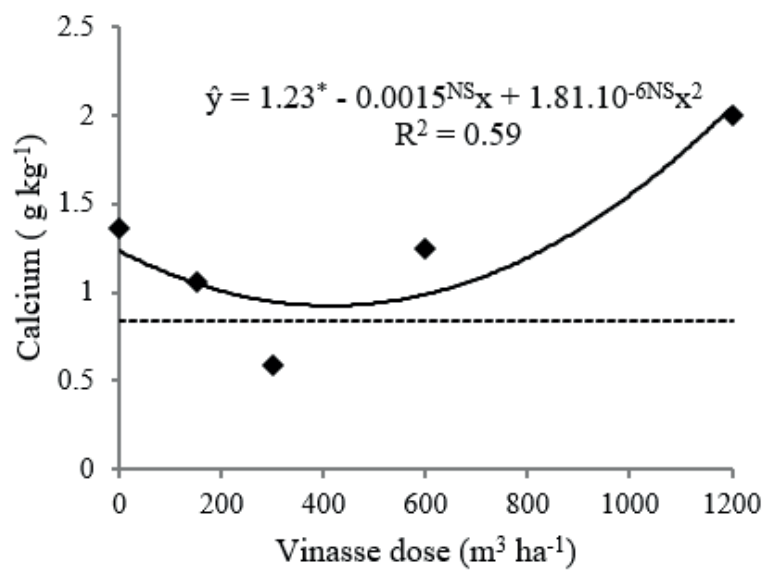

Figure 1. Concentrations of nitrogen (a), phosphorus (b), potassium (c), calcium (d) and magnesium (e) in the top visible dewlap leaf $(+1)$ of sugarcane according to the application of vinasse doses (D0 to D1200) and mineral fertilizer at 120 days after planting.

------ Mineral fertilizer; Means of vinasse doses

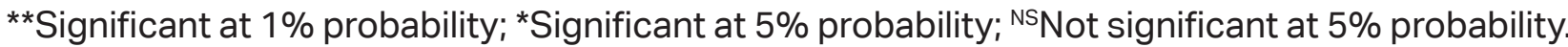


The obtained results suggest that the vinasse doses applied were not sufficient to provide $\mathrm{P}$ levels comparable to those obtained with mineral fertilization, which generally supplied higher levels of the nutrient to the leaf (Figure 1b). These findings are possibly due to the low concentration of phosphate in vinasse (6.8 $\mathrm{mg} \mathrm{L}^{-1}$ ) (Table 2), which was reflected in the low supply of the nutrient to the soil and, consequently, in the lower leaf levels of the nutrient, as compared with mineral fertilization.

The vinasse doses applied were not sufficient to provide $P$ content in the TVD leaf deemed adequate for the crop. According to F. C. Silva (2009), the range of adequate $P$ content is between 1.5 and $3.0 \mathrm{~g} \mathrm{~kg}^{-1}$. The $\mathrm{N}$ and $\mathrm{P}$ levels in the TVD leaf of sugarcane obtained in the present study corroborate those obtained by J. Silva, Cazetta and Togoro (2015), who examined the effects of the vinasse application to the soil on the mineral nutrition of sugarcane and did not find significant increases in the $\mathrm{N}$ or $\mathrm{P}$ concentrations in the TVD leaf. Likewise, Carvalho, Andreotti, Buzetti and Carvalho (2013) evaluated the yield of sugarcane as a function of the use of plaster and vinasse and observed that the application of up to 200 m3 ha-1 of vinasse did not cause a significant change in $\mathrm{N}$ or $\mathrm{P}$ concentrations in the leaf.

At 120 days, significant interaction effects of MF $\times$ DO, MF $\times$ D300 and DO $\times$ vinasse dose (D150 to D1200) were found for $K$ content (Table 5). The application of MF resulted in higher $\mathrm{K}$ content in the TVD leaf $\left(12.9 \mathrm{~g} \mathrm{~kg}^{-1}\right)$ as compared with no vinasse application (12.3 $\mathrm{g} \mathrm{kg}^{-1}$ ) (Table 4). The application of the D300 dose provided higher content of the nutrient in the leaf $\left(14.1 \mathrm{~g} \mathrm{~kg}^{-1}\right)$ when compared with MF (12.9 $\left.\mathrm{g} \mathrm{kg}^{-1}\right)$. When comparing only the application of vinasse doses, we observe that any level would provide higher $\mathrm{K}$ content in leaf than that achieved with non-application of the waste (Figure 1c). As also shown in Figure 1c, starting at the vinasse dose of $144.8 \mathrm{~m}^{3} \mathrm{ha}^{-1}$, the $\mathrm{K}$ content in leaf was already higher than that obtained with mineral fertilization.

The vinasse doses applied provided $\mathrm{K}$ levels in the TVD leaf considered adequate (10 and $16 \mathrm{~g} \mathrm{~kg}^{-1}$ ) by F. C. Silva (2009), except for the D1200, which caused a concentration of the nutrient $\left(18.0 \mathrm{~g} \mathrm{~kg}^{-1}\right)$ above the maximum recommended (Figure 1c). This result can be attributed to the high concentration of the nutrient (1053 $\left.\mathrm{mg} \mathrm{L}^{-1}\right)$ in the composition of vinasse (Table 2).

Borges et al. (2015) evaluated the application of vinasse on the nutritional status and sugarcane yield in an organic cultivation system and found that $K$ from vinasse applied at the dose of $600 \mathrm{~m}^{3} \mathrm{ha}^{-1}$ increased the nutrient content in the TVD leaf of the crop by $44.5 \%$ in relation to mineral fertilization. According to Silveira, Vitusso and Medina (2015), the sugarcane plant accumulates most of the $\mathrm{K}$ present in the tissues during the first months of development. Coupling this with the fact that vinasse adds large amounts of $K$ to the soil, the plant is able to absorb most of this available nutrient even if it is not needed, and from that period on it may exhibit physiological and morphological disorders caused by the excess of the nutrient itself.

For both the $\mathrm{Ca}$ and $\mathrm{Mg}$ contents in the TVD leaf, the test of contrasts (Table 5) indicated significant differences for MF $\times$ D0, MF $\times$ D300 and D0 $\times$ vinasse doses (D150 to D1200). The application of MF resulted in higher $\mathrm{Ca}(0.8 \mathrm{~g}$ $\left.\mathrm{kg}^{-1}\right)$ and $\mathrm{Mg}\left(0.7 \mathrm{~g} \mathrm{~kg}^{-1}\right)$ contents in TVD leaf as compared with D300, which provided $\mathrm{Ca}$ and Mg contents of 0.6 and $0.7 \mathrm{~g} \mathrm{~kg}^{-1}$, respectively. 
In the analysis of the isolated effect of vinasse doses on the leaf levels of $\mathrm{Ca}$ (Figure 1d) and $\mathrm{Mg}$ (Figure 1e), the doses applied were found to provide higher values of these nutrients in the plants than mineral fertilization.

The application of vinasse doses provided $\mathrm{Ca}$ and $\mathrm{Mg}$ contents in the TVD leaf below those indicated as adequate (2 to $8 \mathrm{~g} \mathrm{~kg}^{-1}$ for Ca and 1 to $3 \mathrm{~g} \mathrm{~kg}^{-1}$ for $\mathrm{Mg}$ ) by $\mathrm{F}$. C. Silva (2009), except for the D1200 dose, which resulted in a leaf Ca content $\left(2.03 \mathrm{~g} \mathrm{~kg}^{-1}\right)$ considered adequate for the crop (Figure 1d). These results can be attributed to the low concentrations of $\mathrm{Ca}\left(888.3 \mathrm{mg} \mathrm{L}^{-1}\right)$ and $\mathrm{Mg}$ (395.3 $\mathrm{mg} \mathrm{L}^{-1}$ ) (Table 2) in the composition of the applied vinasse, which, overall, resulted in leaf nutrient contents below the recommended for the crop.

Carvalho et al. (2013) examined the productive of sugarcane in response to the use of plaster and vinasse and observed a low concentration of $\mathrm{Mg}$ in the TVD leaf of the crop $\left(0.78 \mathrm{~g} \mathrm{~kg}^{-1}\right)$ following the application of 200 $\mathrm{m}^{3} \mathrm{ha}^{-1}$ of vinasse. For $\mathrm{Ca}$, the authors found content considered to be adequate for the crop (2.6 $\mathrm{g} \mathrm{kg}^{-1}$ ). Borges et al. (2015) evaluated the application of vinasse, in an organic cultivation system, on the nutritional status and yield of sugarcane and found that the application of the $600 \mathrm{~m}^{3} \mathrm{ha}^{-1}$ dose did not contribute to the adequate nutrition of the crop and that the $\mathrm{Ca}$ and $\mathrm{Mg}$ levels in the TVD leaf remained below recommended.

V. S. G. Silva et al. (2017) investigated the nutritional status of sugarcane varieties and found higher average $\mathrm{K}$ levels in the TVD leaf of the crop than $\mathrm{Ca}$ and $\mathrm{Mg}$. According to Nascimento, Souza, Moreira and Moraes (2017), vinasse doses applied to the soil increase the $\mathrm{K}$ content of plants, but can reduce their $\mathrm{Ca}$ and Mg levels.
The higher $\mathrm{K}$ contents in relation to $\mathrm{Ca}$ and $\mathrm{Mg}$ found in this study may be related to the low CEC of the roots shown by sugarcane, considering that monocotyledonous roots have low root $\mathrm{CEC}$, preferring the absorption of monovalent cations such as K (Büll, Mello, Soares, \& Boareto 1993). In view of this, adequately supplying the soil with $\mathrm{Ca}$ and $\mathrm{Mg}$ is of paramount importance to allow these nutrients to compete for binding sites in the root system of the crop, given the greater preference for the absorption of $\mathrm{K}$, which has a competitive inhibition on the absorption of $\mathrm{Ca}$ and $\mathrm{Mg}$.

Macronutrient ( $N, P, K, C a$ and $M g$ ) and sodium (Na) accumulation in the aerial part

The test of orthogonal contrasts (Table 6) revealed a significant difference for $M F \times D 0$ on the accumulations of $\mathrm{N}, \mathrm{K}, \mathrm{Mg}$ and $\mathrm{Na}$, with higher values obtained with the application of MF (Table 7). As can also be seen in Table 6 , when MF is contrasted with D300, larger Ca accumulation $\left(11.9 \mathrm{~g} \mathrm{~kg}^{-1}\right)$ is obtained with the use of the D300 dose (Table 7). The contrast between DO and vinasse doses (D150 to D1200) (Table 6) showed that the application of vinasse provides larger accumulations of $N, P, K$ and $\mathrm{Na}$ (Table 7). As regards the accumulations of $\mathrm{Ca}$ and $\mathrm{Mg}$, as observed for the levels of these nutrients in the TVD leaf of the crop (Table 4), the application of vinasse doses reduced their accumulations in comparison with the levels obtained with non-application of the waste (DO) (Table 7). 
Table 6

Orthogonal contrasts comparing the effect of mineral fertilizer (MF) and vinasse doses (D0 to D1200) on the accumulation of nitrogen $(\mathrm{N})$, phosphorus $(\mathrm{P})$, potassium $(\mathrm{K})$, calcium $(\mathrm{Ca})$, magnesium $(\mathrm{Mg})$ and sodium $(\mathrm{Na})$ in the aerial part of the sugarcane crop at 210 days after planting

\begin{tabular}{|cccccc|}
\hline & \multicolumn{5}{c}{ F-value } \\
\cline { 2 - 6 } Contrast & $\mathrm{N}$ & $\mathrm{K}$ & $\mathrm{Ca}$ & $\mathrm{Mg}$ & $\mathrm{Na}$ \\
\hline $\mathrm{MF} \times$ Vinasse (D150 to D1200) & $1.87^{\mathrm{NS}}$ & $0.02^{\mathrm{NS}}$ & $0.12^{\mathrm{NS}}$ & $0.41^{\mathrm{NS}}$ & $0.00^{\mathrm{NS}}$ \\
\hline $\mathrm{MF} \times \mathrm{DO}$ & $17.11^{*}$ & $32.38^{*}$ & $3.35^{\mathrm{NS}}$ & $4.43^{*}$ & $19.37^{*}$ \\
MF $\times$ D300 & $0.50^{\mathrm{NS}}$ & $0.38^{\mathrm{NS}}$ & $9.21^{*}$ & $0.86^{\mathrm{NS}}$ & $0.04^{\mathrm{NS}}$ \\
MF $\times$ D1200 & $2.77^{\mathrm{NS}}$ & $0.61^{\mathrm{NS}}$ & $0.29^{\mathrm{NS}}$ & $0.07^{\mathrm{NS}}$ & $0.00^{\mathrm{NS}}$ \\
$\mathrm{DO} \times$ Vinasse (D150 to D1200) & $19.70^{*}$ & $71.17^{*}$ & $10.39^{*}$ & $16.29^{*}$ & $43.16^{*}$
\end{tabular}

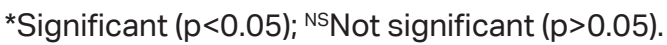

Table 7

Effect of mineral fertilizer (MF) and vinasse doses (D0 to D1200) on the accumulations of nitrogen (N), phosphorus $(\mathrm{P})$, potassium $(\mathrm{K})$, calcium $(\mathrm{Ca})$, magnesium $(\mathrm{Mg})$ and sodium $(\mathrm{Na})$ in the aerial part of the sugarcane crop at 210 days after planting

\begin{tabular}{ccccccccc} 
Nutrient & \multicolumn{7}{c}{ Treatment } \\
\cline { 2 - 8 }$\left(\mathrm{g} \mathrm{kg}^{-1}\right)$ & MF & D0 & D150 & D300 & D600 & D1200 & F & P-value $^{1}$ \\
N & $7.87 \pm 1.10^{2}$ & $5.27 \pm 1.10$ & $6.23 \pm 0.78$ & $6.23 \pm 0.78$ & $7.25 \pm 0.78$ & $10.87 \pm 0.78$ & 5.62 & 0.0014 \\
$\mathrm{P}$ & $14.43 \pm 2.59$ & $14.16 \pm 2.59$ & $14.90 \pm 1.83$ & $14.26 \pm 1.83$ & $15.41 \pm 1.83$ & $15.45 \pm 1.83$ & 0.08 & 0.9947 \\
$\mathrm{~K}$ & $7.03 \pm 2.54$ & $9.84 \pm 2.54$ & $11.08 \pm 1.80$ & $11.76 \pm 1.80$ & $10.87 \pm 1.80$ & $27.58 \pm 1.80$ & 14.86 & $<0.0001$ \\
$\mathrm{Ca}$ & $9.62 \pm 4.15$ & $12.81 \pm 4.15$ & $11.88 \pm 2.94$ & $18.45 \pm 2.94$ & $7.64 \pm 2.94$ & $3.50 \pm 2.94$ & 8.28 & 0.0001 \\
$\mathrm{Mg}$ & $0.83 \pm 0.15$ & $0.78 \pm 0.15$ & $0.59 \pm 0.10$ & $0.61 \pm 0.10$ & $0.67 \pm 0.10$ & $1.16 \pm 0.10$ & 4.06 & 0.0082 \\
$\mathrm{Na}$ & $0.60 \pm 0.14$ & $0.61 \pm 0.14$ & $0.64 \pm 0.10$ & $0.58 \pm 0.10$ & $0.66 \pm 0.10$ & $1.40 \pm 0.10$ & 9.13 & $<0.0001$ \\
\hline
\end{tabular}

${ }^{1}$ Results significant at $5 \%$ (p-value $\left.<0.05\right)$. ${ }^{2}$ Mean \pm standard error. F: F value calculated in analysis of variance.

Nitrogen accumulation increased linearly, by $0.0045 \mathrm{~g} \mathrm{~kg}^{-1}$, with each additional unit of vinasse (Figure 2a). The highest accumulation observed for this macronutrient was $10.54 \mathrm{~g} \mathrm{~kg}^{-1}$, which was estimated with the application of the vinasse dose corresponding to $1200 \mathrm{~m}^{3} \mathrm{ha}^{-1}$, representing a $51.2 \%$ percentage increase in relation to DO.

These results highlight the need for nitrogen fertilization as a complement to the application of vinasse, regardless of the dose applied. In this respect, Schultz, Lima, Pereira and Zonta (2010) recommended $\mathrm{N}$ dose of up to $80 \mathrm{~kg} \mathrm{ha}^{-1}$ to optimize the yield of sugarcane when fertigated with vinasse.

Phosphorus accumulation by the crop was not significantly influenced by any of the evaluated treatments (Table 7). These results show that even though vinasse has a low $P$ concentration, the amount supplied to the plants by the waste was sufficient to provide an accumulation analogous to that obtained with the application of mineral fertilizer. In addition, the low requirement of the macronutrient 
by the crop may have contributed to these results, since, as described by E. C. A. Oliveira et al. (2010), $P$ is required in the lowest amount among the macronutrients essential to sugarcane.

Considering the accumulation of $\mathrm{K}$ as a function of the vinasse doses applied (Figure $2 b)$, any of the evaluated doses was found to provide a larger accumulation of the nutrient than MF. Also according to Figure 2b, there was an increasing accumulation of the nutrient with the application of doses from $235.1 \mathrm{~m}^{3}$ $\mathrm{ha}^{-1}$. Given these results, it is assumed that the presence of high concentrations of vinasse in the soil may have caused the sugarcane to absorb more $\mathrm{K}$ than its actual requirement for maximum yield (luxury uptake). In this respect, Oliveira, Medeiros, Freire, Simões and Oliveira (2016) described that when present in higher concentrations in the soil solution, the high concentrations of $\mathrm{K}$ in vinasse associated with the preference of the crop to absorb the nutrient can contribute to the achievement of more marked accumulations of $\mathrm{K}$ in the plant. (a)

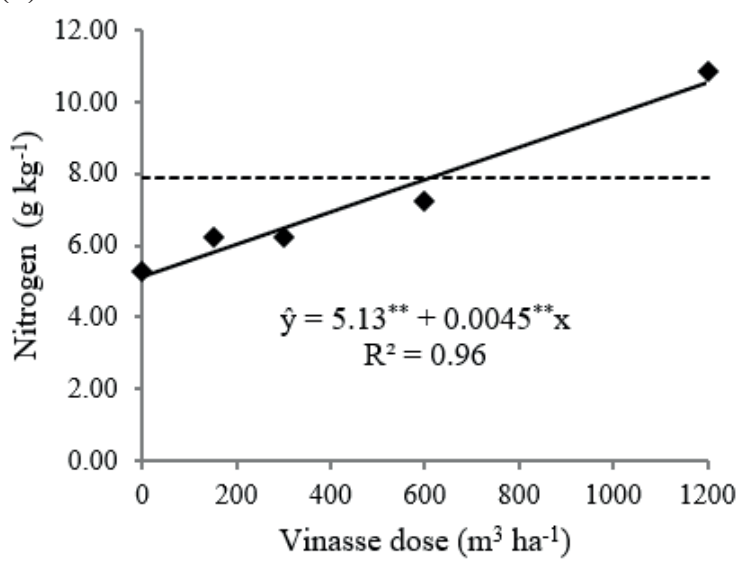

(c)

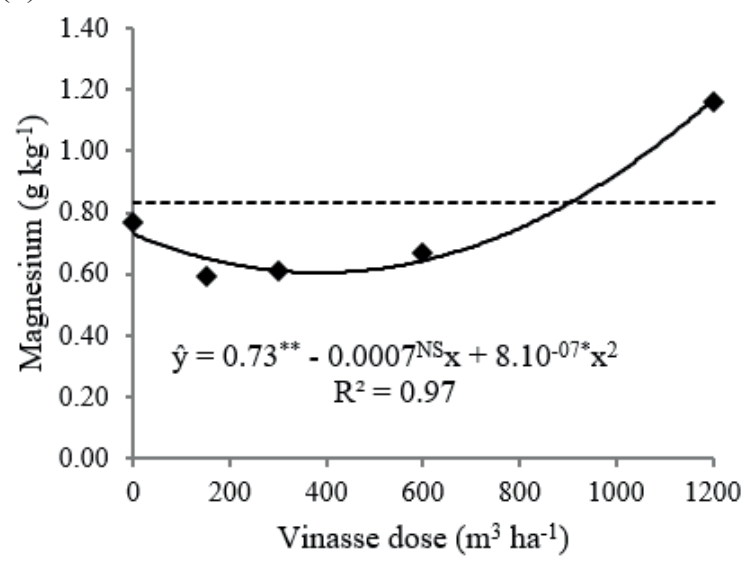

(b)

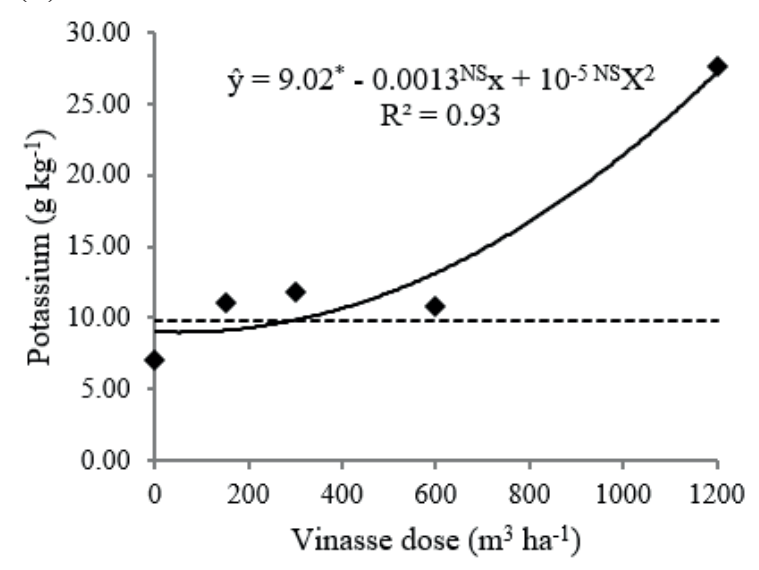

(d)

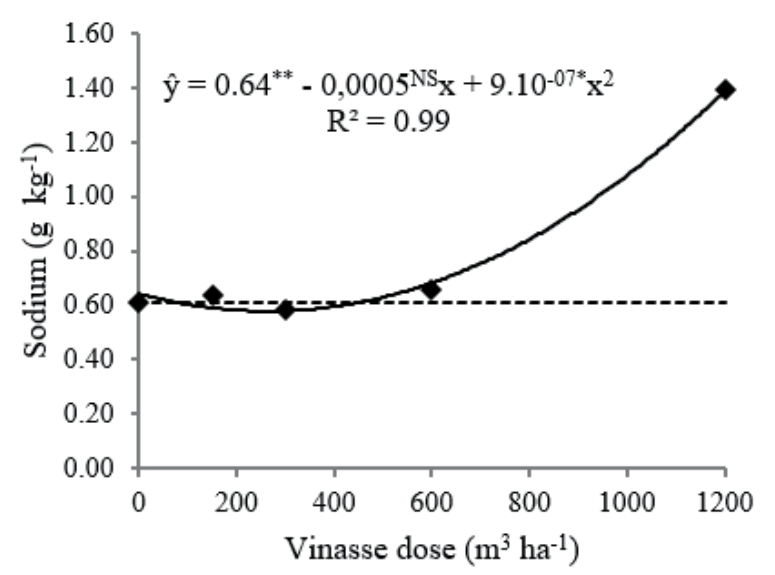

Figure 2. Accumulation of nitrogen (a), potassium (b), magnesium (c) and sodium (d) in the aerial part of the sugarcane crop according to the application of mineral fertilizer and vinasse doses (D0 to $D 1200)$ at 210 days after planting.

------ Mineral fertilizer; Means of vinasse doses

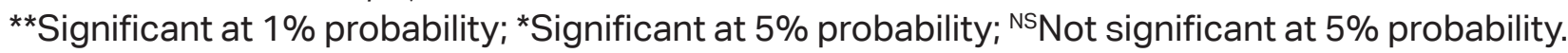


According to Zörb, Senbayram and Peiter (2014), luxury uptake associated with high availability of $\mathrm{K}$ in the soil occurs when there are high concentrations of $K$ in the tissues. Besides the physiological need of the plant, $\mathrm{K}$ absorption can occur through the efficient mechanisms of absorption and distribution throughout the cells and the plant, with the cytoplasm and vacuole being the compartments used in the plant to store the absorbed nutrient (Ahmad \& Maathuis, 2014). In addition to this, the cultivar evaluated in this study, RB867515, also has high affinity for the nutrient (R. I. Oliveira et al., 2016).

For $\mathrm{Ca}$ accumulation, there was no difference in the evaluated contrasts between MF and vinasse doses (D150 to D1200) (Table 6). However, among the applied doses of the waste, D600 and D1200 provided less accumulation of the nutrient by the crop than the other tested doses (D0, D150 and D300) (Table 7).

An antagonistic interaction was observed between $\mathrm{K}$ and $\mathrm{Ca}$. These cations are known to possibly compete for the same absorption sites; however, sugarcane has preference for K. Malavolta (2006) stated the antagonism between $\mathrm{K}$ and $\mathrm{Ca}$, as well the advantage of $\mathrm{K}$ because it is monovalent and has lower degree of hydration, in addition to being more mobile in the soil. Thus, under high amounts of $\mathrm{K}$, the plant absorbs less $\mathrm{Ca}$, as was observed in D600 and D1200.

Rhodes et al. (2018) evaluated the interaction of $\mathrm{K}$ with $\mathrm{Ca}$ in sugarcane and reported that the $\mathrm{Ca}$ content of the TVD leaf was suppressed by the presence of $\mathrm{K}$ in proportion to its availability in the soil. Also according to the authors, this is due to the relationship that $\mathrm{K}$ ions have with $\mathrm{H}$ ions, as they share the same transmembrane transport protein, which facilitates their absorption by the plant to the detriment of $\mathrm{Ca}$. In the present study, among the evaluated treatments, from D300, the supply of $K$ was sufficient to allow the plant to absorb less $\mathrm{Ca}$.

There was no difference for $\mathrm{Mg}$ accumulation when contrasting MF $\times$ vinasse doses (D150 to D1200) (Table 6). From the dose corresponding to $437.5 \mathrm{~m}^{3} \mathrm{ha}^{-1}$, there was an increase in the accumulation of the nutrient by the crop (Figure 2c). The contrast of MF $\times$ vinasse doses (D150 to D1200) did not reveal a significant effect on $\mathrm{Na}$ accumulation by the plants (Table 6). However, comparing the vinasse doses in relation to the accumulation of the element by the plants (Figure $2 \mathrm{~d}$ ), the application of vinasse doses as low as to or greater than $490 \mathrm{~m}^{3}$ ha $^{-1}$ provided a larger accumulation of sodium in the plants than that obtained with the application of MF.

The accumulation of K and Na occurring at vinasse doses greater than $277 \mathrm{~m}^{3} \mathrm{ha}^{-1}$ (Figures $2 \mathrm{~b}$ and $2 \mathrm{~d}$, respectively) is explained by the fact that these ions are monovalent and, as such, compete with each other at the moment of absorption. In the present study, the $\mathrm{K}$ concentration in vinasse (1053 $\left.\mathrm{mg} \mathrm{L}^{-1}\right)$ was $44.4 \%$ higher than its $\mathrm{Na}$ concentration (729.1 $\mathrm{mg} \mathrm{L}^{-1}$ ), which may have contributed to the predominance of $\mathrm{K}$ over $\mathrm{Na}$ and, consequently, to the preference for the absorption of the nutrient over $\mathrm{Na}$. In this regard, Benito, Haro, Amtmann, Cuin and Dreyer (2014) stated that the plant has preference for $\mathrm{K}$ absorption over $\mathrm{Na}$ and that this preference will depend on the concentration of $\mathrm{Na}$ in the medium in relation to the concentration of $\mathrm{K}$.

Figure 3 shows the order of accumulation of nutrients according to each 
treatment. As illustrated, $\mathrm{P}$ was the nutrient accumulated in largest quantity, despite the low concentration found in vinasse. Sugarcane started to accumulate more $\mathrm{K}$ than $\mathrm{Ca}$ from D600, whereas $\mathrm{N}, \mathrm{Mg}$ and $\mathrm{Na}$ were the least absorbed nutrients. Oliveira, Freire, Oliveira, Oliveira and Freire (2011) stated that maximum $\mathrm{P}$ and $\mathrm{K}$ accumulation in sugarcane occurs in the early stages of development.

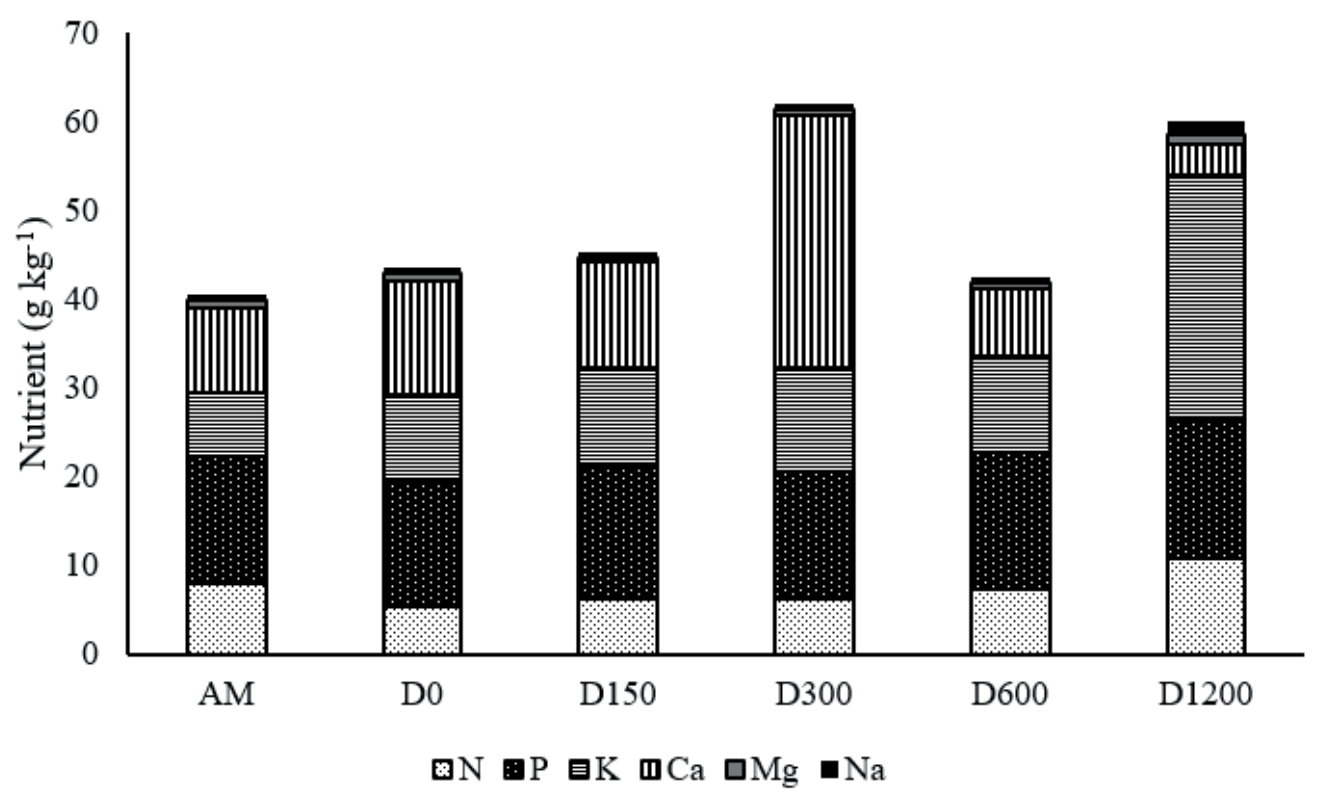

Figure 2. Order of accumulation of macronutrients and sodium in sugarcane according to vinasse doses (D0, D150, D300, D600 and D1200) and mineral fertilizer (MF) at 210 days after planting.

\section{Conclusions}

The vinasse doses applied did not increase the leaf contents of macronutrients sufficiently to be considered enough to adequate cultivation of sugarcane;

The highest leaf contents of $\mathrm{N}$ and $P$ in the crop, at 120 days, were obtained with mineral fertilization. For $\mathrm{K}, \mathrm{Ca}$ and $\mathrm{Mg}$, the highest levels were achieved with the application of the highest doses of vinasse (600 and $1200 \mathrm{~m}^{3} \mathrm{ha}^{-1}$ );
Up to 210 days after planting, the application of the highest doses of vinasse (600 and $1200 \mathrm{~m}^{3} \mathrm{ha}^{-1}$ ) provided larger accumulations of $\mathrm{N}, \mathrm{P}, \mathrm{K}$ and $\mathrm{Na}$. However, they did not favor the accumulation of $\mathrm{Ca}$, whose maximum value was reached with the application of $300 \mathrm{~m}^{3} \mathrm{ha}^{-1}$ of vinasse;

The descending order of macronutrients and $\mathrm{Na}$ accumulation at 210 days after planting by sugarcane under mineral fertilizer was $\mathrm{P}>\mathrm{Ca}>\mathrm{N}>\mathrm{K}>\mathrm{Mg}>\mathrm{Na}$; under application of vinasse, $\mathrm{K}>\mathrm{P}>\mathrm{Ca}>\mathrm{N}>\mathrm{Na}>\mathrm{Mg}$; and in the absence of mineral fertilization and vinasse, $\mathrm{P}>\mathrm{Ca}>\mathrm{K}>\mathrm{N}>\mathrm{Mg}>\mathrm{Na}$. 


\section{Acknowledgments}

Thanks are due to the Coordination for the Improvement of Higher Education Personnel (CAPES) for the Doctoral fellowship granted to the first author and to the Federal Rural University of Pernambuco (UFRPE) for the teaching conditions and for allowing the use of the area for the development of research.

\section{References}

Ahmad, I., \& Maathuis, J. M. (2014). Cellular and tissue distribution of potassium: physiological relevance, mechanisms and regulation. Journal of Plant Physiology, 171(9), 708-714. doi: 10.1016/j.jplph.2013. 10.016

Aquino, G. S., Medina, C. C., Brito, O. R., \& Fonseca, I. C. B. (2015). Changes in soil chemical reactions in response to straw sugar cane and vinasse. Semina: Ciências Agrárias, 36(4), 2493-2506. doi: 10.5433/ 1679-0359.2015v36n4p2493

Barbosa, E. A. A., Arruda, F. B., Pires, R. C. M., Silva, T. J. A., \& Sakai, E. (2012). Cana-deaçúcar fertirrigada com vinhaça e adubos minerais via irrigação por gotejamento subsuperficial: ciclo da cana-planta. Revista Brasileira de Engenharia Agrícola e Ambiental, 16(9), 952-958. doi: 10.1590/ S1415-43 662012000900005

Benito, B., Haro, R., Amtmann, A., Cuin, T. A., \& Dreyer, I. (2014). The twins $\mathrm{K}+$ and $\mathrm{Na}+$ in plants. Journal of Plant Physiology, 171(9), 723-731. doi: 10.1016/j.jplph.2013.10.014

Borges, L. de A. B., Madari, B. E., Leandro, W. M., Fernandes, P. M., Silva, E. A., Silva, M. R., \& Silva, M. A. S. (2015). Nutritional state and productivity of organic sugarcane in Goias, Brazil. Journal of Agronomy, 14(1), 6-14. doi: 10.3923/ja.2015.6.14

Büll, L. T., Mello, A. F., Soares, E., \& Boareto, A. E. (1993). Influência da relação K/(Ca + $\mathrm{Mg}$ ) do solo na produção de matéria seca e na absorção de potássio por gramíneas e leguminosas forrageiras: I. Absorção de potássio em função da espécie vegetal. Cientifica, 21, 55-66.

Carvalho, J. M., Andreotti, M., Buzetti, S., \& Carvalho, M. P. (2013). Produtividade de cana soca sem queima em função do uso de gesso e vinhaça. Pesquisa Agropecuária Tropical, 43(1), 1-9. doi: 10. 1590/S1983-40632013000100001

Cavalcanti, F. L. A.; Santos, J. C. P.; Pereira, J. R.; Leite, J. P.; Silva, M. C. L.; Freire, F. J.,... Lima, J. F. W. F. (2008). Recomendações de adubação para o estado de Pernambuco: $2^{a}$ aproximação (3a ed.). Recife: Instituto Agronômico de Pernambuco, IPA.

Christofoletti, C. A., Escher, J. P., Correia, J. E., Marinho, J. F. U., \& Fontanetti, C. S. (2013). Sugarcanevinasse: environmental implications of its use. Waste Management, 33(12), 2752-2761. doi: 10.1016/j. wasman.2013.09.005

Franco, H. C. J., Otto, R., Faroni, C. E., Vitti, A. C., Oliveira, E. C. A., \& Trivelin, P. C. O. (2011). Nitrogen in sugarcane derived from fertilizer under Brazilian field conditions. Field Crops Research, 121(1), 29-41. doi: 10.1016/j.fcr.2010.11.011

Garcia, C. F. H., Souza, R. B., Souza, C. P., Christofoletti, C. A., \& Fontanetti, C. S. (2017). Toxicity of two effluents from agricultural activity: comparing the genotoxity of sugar cane and orange 
vinasse. Ecotoxicologyand Environmental Safety, 142, 216-221. doi: 10.1016/j. ecoenv.2017.03.053

Grangeiro, L. C., Oliveira, F. C. L., Negreiros, M. Z., Marrocos, S. T. P., Lucena, R. R. M., \& Oliveira, R. A. (2011). Crescimento e acúmulo de nutrientes em coentro e rúcula. Revista Brasileira de Ciências Agrárias, 6(1), 11-16. doi: 10.5039/agraria. v6i1a634

Malavolta, E. (2006). Manual de nutrição mineral de plantas. São Paulo: Editora Agronômica Ceres.

Martinez, H. E. P., Carvalho, J. G., \& Souza, R. B. (1999). Diagnose foliar. In: A. C. Ribeiro, P. T. G. Guimarães, V. V. H. Alvarez (Eds.), Recomendações para o uso de corretivos e fertilizantes em Minas Gerais - $5^{\circ}$ Aproximação (pp. 126-151). Viçosa, MG: Comissão de Fertilidade do Solo do Estado de Minas Gerais.

Meyer, J. H. (2013). Sugarcane nutrition and fertilization. In: J. H. Meyer, P. Rein, P., \& Turner, K. Mathias (Eds.), Good management practices for the cane industry (pp. 133-180). Berlin, Germany: Bartens.

Nascimento, R., Souza, J. A., Moreira, A., \& Moraes, L. A. C. (2017). Phosphogypsum and vinasse application: soil chemical properties and alfafa productivity and nutritional characteristics. Revista Caatinga, 30(1), 213-219. doi: 10.1590/1983-21252017v30n123rc

Oliveira, E. C. A., Freire, J. F., Oliveira, R. I., Freire, M. B. G. S., Simões, D. E., Neto, \& Silva, S. A. M. (2010). Extração e exportação de nutrientes por variedades de cana-deaçúcar cultivadas por irrigação plena.
Revista Brasileira de Ciência do Solo, 34(4), 1343-1352. doi: 10.1590/S010006832010000400031

Oliveira, E. C. A., Freire, J. F., Oliveira, R. I., Oliveira, A. C., \& Freire, M. B. G. S. (2011). Acúmulo e alocação de nutrientes em cana-deaçúcar. Revista Ciência Agronômica, 42(3), 579-588.

Oliveira, R. I., Medeiros, M. R. F. A., Freire, C. S., Simões, D. E., Neto, \& Oliveira, E. C. A. (2016). Nutrient partitioning and nutritional requirement in sugarcane. Australian Journal of Crop Science, 10(1), 69-75.

Ortegón, G.P.,Arboleda,F.M.,Candela,L., Tamoh, K., \& Valdes-Abellan, J. (2016). Vinasse application to sugar cane fields. Effect of the unsaturated zone and groundwater at Valle del Cauca (Colombia). Science of the Total Environment, 539, 410-419. doi: 10.1016/j.scitotenv.2015.08.153

Pazuch, F. A., Nogueira, C. E. C., Souza, S. N. M., Micuanski, V. C., Friedrich, L., \& Lenz, A. M. (2017). Economic evaluation of the replacement of sugar cane bagasse by vinasse, as a souce of energy in a power plant in the state of Paraná, Brazil. Renewable and Sustainable Energy Reviews, 76, 34-42. doi: 10.1016/j.rser.20 17.03.047

Rhodes, R., Miles, N., \& Hughes, J. C. (2018). Interactions between potassium, calcium, and magnesium in sugarcane grown on two contrasting soils in South Africa. Field Crops Research, 223, 1-11. doi: 10.10 16/j. fcr.2018.01.001

Ribeiro, A. C., Guimarães, P. T. G., \& Alvarez, V. V. H. (Eds.). (1999). Recomendações para o uso de corretivos e fertilizantes em Minas Gerais. Viçosa, MG: CFSEMG. 
Schultz, N., Lima, E., Pereira, M. G., \& Zonta, E. (2010). Efeito residual da adubação na cana-planta e da adubação nitrogenada e potássica na cana-soca colhidas com e sema queima da palhada. Revista Brasileira de Ciência do Solo, 34(3), 811-820. doi: 10.1590/S0100-06832010000300023

Silva, F. C. (Ed.). (2009). Manual de análises química de solos, plantas e fertilizantes (2a ed.). Brasília, DF: EMBRAPA Informação Tecnológica.

Silva, J., Cazetta, J., \& Togoro, A. (2015). Soil change induced by the application of biodigested vinasse concentrate, and its effects on growth of sugarcane. Chilean Journal of Agricultural Research, 75(2), 249-254. doi: 10.4067/S071858392015000200015
Silva, V. S. G., Oliveira, M. W., Oliveira, D. C., Oliveira, T. B. A., Pereira, M. G., \& Nogueira, C. H. C. (2017). Nutritional diagnosis of sugarcane varieties in a Yellow Oxisoil during three agricultural seasons. African Journal of Agricultural Research, 12(1), 50-57. doi: 10.5897/AJAR2016.11865

Silveira, M. A. G., Vitusso, L., \& Medina, N. H. (2015). Distribuição de potássio em canade-açúcar. Brazilian Journal of Radiation Sciences, 3(1A), 1-8. doi: 10.15392/bjrs. v3i1A.138

Zörb, C., Senbayram, M., \& Peiter, E. (2014). Potassium in agriculture - Status and perspectives. Journal of Plant Physiology, 171(9), 656-669. doi: 10.1016/j.jplph.2013. 08.008 